\title{
MERANCANG IKLAN WEB UNTUK IKLAN LAYANAN MASYARAKAT PADA WEBSITE KEMENKES RI DENGAN MENGGUNAKAN GOOGLE WEB DESIGNER
}

\author{
Ni Luh Putu Ratna Suandari ${ }^{1)}$, Anung Rachman ${ }^{2)}$ \\ Prodi Desain Komunikasi Visual, Fakultas Seni Rupa dan Desain \\ Institut Seni Indonesia Surakarta, Jl. Ki Hajar Dewantara No. 19 Surakarta \\ ratnasuandari23@gmail.com, anung@isi-ska.ac.id
}

\begin{abstract}
Currently the outbreak of the covid-19 virus is increasingly rampant, where the covid-19 virus is a new virus, and the public is still lay with the covid-19 virus. Therefore, the Ministry of Health made public service advertisement (PSA) about covid-19 so that the public is more aware of the covid-19 virus and the life that must be lived at this time. However, this does not have a significant effect, because not many people visit and know about the ministry of health website. For the information submitted in the ministry of health PSA to be delivered, the creation of web advertisements for the Ministry of Health website needs to be designed to increase the audience that sees. Therefore, web ads would be created using Google Web Designer features designed with responsive design. In the creation of this web ad using sprint design method consisting of five stages, namely understand, diverge, decide, prototype, and validate. At these stages explained the process in designing web advertisements about Covid-19 PSA contained on the website of the Ministry of Health. In addition, in the process of designing web advertising from start to finish is done qualitatively. From the stage carried out in the design of web advertising was obtained the result that web ads help increase audience's awareness about covid-19 PSA.
\end{abstract}

Key Word: Covid-19, Design Responsive, Design Sprint, Public Service Advertising, Web Advertising

Relevance to Visual Communication Design Pratice: In this paper, audience can learn about web advertising that can help to increase audience's awareness.

\section{PENDAHULUAN}

Dewasa ini seluruh dunia dikejutkan dengan wabah penyakit baru, wabah ini tidak hanya menyerang sektor kesehatan namun juga menyerang sektor perekonomian, pariwisata, dan lain-lain. Wabah penyakit ini datang karena adanya virus baru yang disebut virus Severe Acute Respiratory Syndrome Coronavirus-2 (SARS -coV-2) (Anung Ahadi Pradana, Casman, 2020). Virus covid-19 ini menyerang sistem pernapasan manusia, gejala yang ditimbulkan hampir mirip seperti SARS, flu burung, flu babi, dan MERS namun yang membedakannya, virus ini mudah menular
(Agung, 2020). Wabah penyakit covid-19 pertama kali muncul di kota Wuhan, China pada tahun 2019 dan kemunculan virus inipun masih dipertanyakan (Agung, 2020). Menurut WHO yang dikutip oleh Jurnal Pekerjaan Sosial menyatakan bahwa virus covid-19 merupakan virus yang sangat berbahaya, sebab virus ini merupakan pandemic global di mana hampir seluruh dunia terinfeksi oleh virus ini yang jumlahnya mencapai lebih dari 121.000 kasus (Ilpaj and Nurwati, 2020). Tingginya kasus kematian yang ditimbulkan virus covid-19 disebabkan karena proses penularan penyakit ini begitu cepat, di mana penyakit ini dapat 
menyebar melalui tetesan kecil dari hidung atau mulut seseorang terinfeksi virus covid-19 yang keluar dari batuk, pilek, hingga saat berbicara. Oleh karena itu, saat ini perlu menjaga diri sendiri serta orang lain agar terhindar dari penyakit virus covid-19.

Munculnya wabah penyakit covid-19 di Indonesia yaitu pada bulan Maret tahun 2020 (Anung Ahadi Pradana, Casman, 2020). Hal ini membuat seluruh masyarakat Indonesia merasa ketakutan dengan keberadaan virus ini, di mana covid-19 merupakan penyakit yang menular ke siapapun serta belum ditemukan obat yang bisa menangkal penyakit tersebut. Pemerintah Indonesia gencar memberikan himbauan kepada masyarakat agar selalu berwaspada serta tidak panik dengan keberadaan covid-19 (Agung, 2020). Selain itu, pemerintah juga melakukan berbagai langkah serta tindakan untuk pencegahan penularan covid-19 seperti mengimbau masyarakat untuk melakukan $3 \mathrm{M}$ yaitu menggunakan masker; mencuci tangan; serta menjaga jarak, selain itu mengimbau masyarakat agar beradaptasi dengan keadaan new normal, serta pemerintah mengimbau masyarakat agar melakukan vaksinasi. Adanya virus covid-19 yang merupakan virus baru dan sebagian masyarakat masih asing mengenai virus tersebut oleh, pemerintah menyebarkan informasi mengenai virus covid-19 dengan menggunakan kecanggihan teknologi berbasis web. Pemerintah selalu memberikan edukasi mengenai covid-19 pada web Kemenkes RI.

Cara tersebut muncul akibat perkembangan IPTEK yang sangat maju, dimana internet dapat menyebarkan sebuah informasi secara cepat dan tanpa menggunakan biaya yang banyak (Sitepu and Tanjung, 2020). Salah satu media massa berbasis online yang berisi sebuah informasi yaitu web. Web merupakan media online berisi informasi yang dapat diakses melalui intenet secara efektif dan efisien (Prabowo, 2020). Penggunaan Media massa web ini sangat ampuh dalam menyebarkan sebuah informasi, karena dimudahkan dalam mencari informasi dengan menggunakan web (Arrosyid, 2020). Menurut data pengguna internet pada tahun 2020 menurut kominfo berjumlah 73,7 persen sekitar 196,7 juta pengguna internet hal ini termasuk salah satu alasan dalam menyebarkan informasi menggunakan web (Irso, no date). Selain itu, penggunaan internet juga mengalami peningkatan karena adanya pandemi covid-19 di mana saat ini disarankan untuk melakakukan komunikasi melalui internet. Dilihat dari penggunaan internet yang begitu tinggi maka efektivitas dalam membuat iklan secara digital bisa membantu pemerintah dalam menyebarkan sebuah informasi.

Berdasar penjelasan latar belakang yang telah disampaikan, penulis tertarik untuk merancang iklan web mengenai kebijakan new normal untuk web mobile dengan menggunakan Google Web Designer. Dimana data mengenai covid-19 sudah tersedia lengkap di web Kemenkes RI kemudian data tersebut dirancang menjadi iklan web dengan menggunakan Google Web Designer, yang dirancang dengan desain responsif. Hal ini merupakan alternatif model Iklan Web yang digunakan untuk meningkatkan volume respon audien terhadap ILM mengenai covid19, selain itu memberikan kontribusi terhadap penyebaran mengenai informasi penting terkait new normal serta virus covid-19. 


\section{LANDASAN TEORI}

\section{Kebijakan New Normal}

Menghadapi virus covid-19, yang penularannya begitu cepat membuat pemerintah Indonesia mengeluarkan sebuah kebijakan untuk mencegah penyebaran covid19 yaitu menerapkan kondisi new normal. Penerapan kebijakan new normal ini dilakukan untuk membantu masyarakat agar bisa melakukan aktivitas pada umumnya, selain itu kebijakan ini merupakan upaya preventif untuk menekan penyebaran kasus covid-19 selama masyarakat melakukan aktivitas di luar rumah. (Januar Mahardhani, 2020). Kebijakan new normal adalah kebijakan yang dibuat pemerintah dalam kondisi pandemic saat ini, dimana terjadi perubahan dalam pola kebiasaan yang dilakukan di mana terdapat pola kehidupan karena adanya pembatasan aktivitas. Saat ini masyarakat ditegaskan untuk berdisplin dalam menjaga kesehatan masingmasing. Pemerintah juga menggencarkan masyarakat untuk mematuhi kebijakan $3 \mathrm{M}$ yaitu mencuci tangan, menjaga jarak, serta menggunakan masker. Menurut LIPI yang terdapat dalam jurnal Abdimas Siliwangi menyatakan bahwa pelaksanaan kenormalan baru yang dibuat pemerintah dalam menanggulangi covid-19 ini harus memiliki rasa aman kepada masyarakat dan terdapat kesinkronan antara pemerintah pusat dan pemerintah daerah dalam menanggulangi covid-19 agar semua berjalan sesuai rencana (Karwati et al., 2021).

\section{Iklan}

Iklan adalah bentuk pesan yang disampaikan kepada konsumen dengan tujuan memberi informasi, membujuk dan mengingatkan konsumen terhadap sebuah produk yang diiklankan. Iklan yang baik yaitu iklan yang memiliki efektivitas iklan yang baik, dimana menurut Sculth \& Tannebaum (dalam prosiding Seminar Nasional Inovasi dan tren 2018) menyatakan bahwa efektivitas iklan dapat dilihat dari pengenalan sebuah produk lalu iklan yang diingat dan pesan iklan yang dipahami (Martana, 2018). Hal ini berarti semakin tinggi efektivitas sebuah iklan maka tidak hanya informasi mengenai produk saja yang bisa menarik target namun pesan yang ada di iklan tersebut yang mampu menarik target untuk melakukan tindakan terhadap sebuah produk. Iklan tidak hanya menjelaskan mengenai produk saja, namun terdapat juga iklan yang menjelaskan mengenai pelayanan yang diberikan oleh pemerintah, iklan itu disebut iklan layanan masyarakat. Iklan layanan masyarakat merupakan sarana yang diberikan oleh pemerintah, organisasi komersil dan non komersil untuk menyampaikan informasi, mengajak dan mendidik khalayak untuk menimbulkan sebuah kesadaran atau mengalami perubahan terhadap masalah yang diiklankan sehingga memberikan dampak positif terhadap diri sendiri (Pratiwi and Hidayat, 2020). Menurut Kamus Istilah Periklanan Indonesia yang temuat dalam Jurnal Akrab Juara, iklan layanan masyarakat memiliki tujuan yaitu meningkatkan kesejahteraan masyarakat dalam bidang sosial maupun sosial-ekonomis (Rudianto et al., 2018).

\section{Web Mobile}

Dalam jurnal teknologi komputer dan sistem informasi, Satyaputra menyatakan website mobile merupakan sistem operasi untuk 
smartphone yang merupakan jembatan antara perangkat dan pengguna sehingga pengguna bisa berinteraksi dengan device dalan menjalankan aplikasi yang tersedia dalam device (Muslihudin and Setiawan, 2019). Selain itu, web mobile merupakan situs web yang dirancang dengan desain yang sederhana dan bersifat memberikan informasi, situs web ini dirancang khusus dalam perangkat mobile (Usmanto et al., 2018). Web mobile, termasuk teknologi baru yang telah mengakomodasi kebutuhan dalam mengakses internet melalui perangkat mobile yaitu sebuah web akan dapat diakses melalui mobile phone (Hakim and Oktariandi, 2017).

\section{Google Web Design}

Google web design adalah sebuah fitur dari google yang membantu membuat konten iklan yang menarik. Selain itu google web designer merupakan aplikasi gratis yang berguna untuk memuat iklan HTML5 dan iklan AMPHTML, tidak hanya itu saja aplikasi ini memiliki fitur lengkap dan memiliki antarmuka visual dan kode. Aplikasi ini sangat mendukung creator dalam membuat iklan, karena jika iklan dibuat semenarik mungkin maka akan banyak masyarakat yang mengunjungi iklan yang dibuat. Fitur web designer ini membantu creator dalam mempercepat pengembangan yaitu template bisa disesuaikan dengan tema yang diambil, komponen bisa ditarik dan dilepas, serta validasi iklan real time. Google web designer ini bisa disatukan dengan Google Ads, Display \& Video 360, Studio, dan Campaign Manager yang mana penyatuan tersebut terjadi karena jika membuat web design dengan google web design data dapat dihubungkan dan alur kerja akan bekerja di seluruh produk Google dan platform iklan. Iklan yang bisa dibuat dengan menggunakan google web design yaitu iklan banner, iklan AMPHTML, iklan reponsif, iklan dinamis, iklan yang dapat diperluas, iklan interstisial. Selain itu, google web designer juga mempunyai fitur membuat iklan dengan mode animasi. Mode animasi ini terbagi menjadi dua bagian yaitu mode cepat (mode yang memudahkan dalam membuat animasi) dan mode lanjutan (memiliki tingkat kerumitan dalam membuat animasi karena menganimasikan elemen satu per satu). Materi mengenai Google Web Design penulis ambil dari materi yang disampaikan oleh Anung Rachmat dalam e-learning ISI Surakarta.

\section{Desain Responsif}

Pembuatan sebuah iklan web dapat dibuat dengan desain responsif adalah iklan yang dirancang dengan berbagai ukuran, dimana tidak perlu merancang materi iklan untuk ukuran layar tertentu (Pramonoadi, 2017) Desain responsif merupakan desain iklan yang bisa menyesuaikan ukuran dan tata letak sesuai dengan ruang iklan yang tersedia. Desain responsif akan memunculkan sebuah iklan dengan ukuran yang berbeda di berbagai tempat. Desain ini adalah sebuah metode dalam membuat desain iklan web agar terlihat fleksibel dengan perangkat pengguna. Selain itu, proses pembuatan iklan desain responsif ini cukup sekali (LALU, 2019). Menurut Knight (2011) dalam thesis yang dibuat oleh Yeni Rori mengatakan bahwa desain responsif merupakan pendekatan yang memberikan kemampuan desain situs dalam beradaptasi terhadap perilaku pengguna situs dengan lingkungan situs (Rori, 2018). Dalam materi yang disampaikan Anung Rachmat dalam $e$ learning ISI Surakarta menyatakan bahwa iklan 
desain responsif dalam dibuat di google web design, di sana sudah terdapat template atau bisa dibuat secara manual, namun ukuran desain responsif ini tidak tersedia untuk iklan AMPHTML.

\section{METODE PENELITIAN}

Berdasarkan latar belakang yang sudah disampaikan, terdapat pertanyaan yaitu bagaimana merancang iklan web untuk iklan layanan masyarakat yang terdapat pada website Kemenkes RI dengan menggunakan Google Web Designer. Dalam menjawab pertanyaan tersebut terdapat beberapa tahapan-tahapan yang perlu dilakukan, hal ini bertujuan agar pengerjaan dapat dilakukan secara sistematis. Penelitian terdiri dari 3 tahap utama yaitu tahap awal, tahap perancangan dan tahap akhir (Rustiaria, 2021). Pada tahap perancangan, penulis menggunakan metode design sprint yang dikembangkan oleh Google (Ramadan, Muslimah and Rokhmawati, 2019). Metode design sprint adalah metode yang digunakan untuk merancang sebuah produk dan prototype dengan menggabungkan ide-ide strategis bisnis, inovasi, desain dan psikologi yang dapat membantu dalam menjawab sebuah masalah yang terjadi. Tahapan dalam proses penelitian ini dapat dilihat pada gambar 3.1.

Berikut tahapan metode yang akan dilakukan pada proses perancangan iklan web:

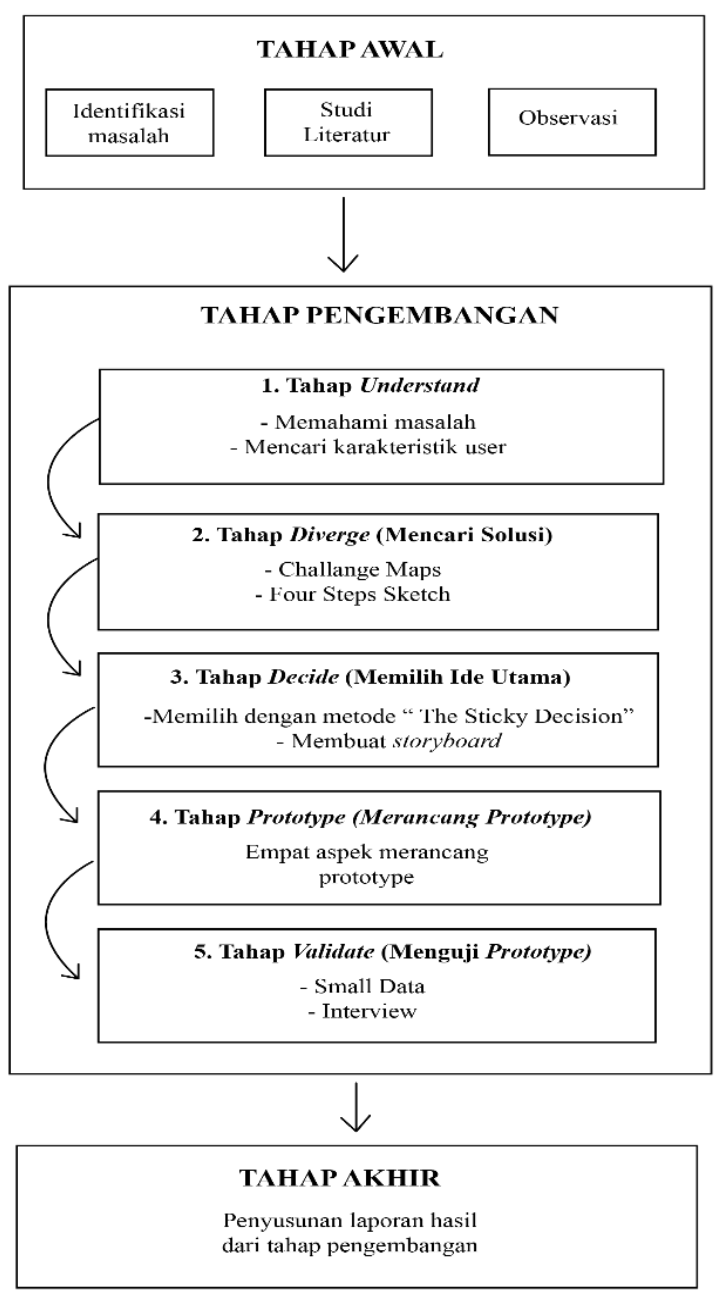

Gambar 1 Tahapan metode yang akan dilakukan oleh penulis.

Sumber: dokumentasi penulis

\section{Tahap Awal}

Pada tahap awal penelitian ini diawali dengan melakukan identifikasi masalah, hal ini bertujuan untuk menentukan masalah dan tujuan penelitian, dalam penelitian ini masalah yang dihadapi yaitu kebijakan new normal yang sedang dihadapi oleh masyarakat Indonesia. Masyarakat masih awam mengenai kebijakan new normal, oleh karena itu permasalahan ini membutuhkan sebuah solusi. Proses identifikasi ini, juga perlu unsur pendukung yaitu dengan studi literatur, yang juga berfungsi sebagai pedoman dalam melaksanakan penelitian untuk membantu memahami 
metode dan teori yang akan digunakan. Studi literatur dilakukan berdasarkan buku referensi, jurnal, laporan penelitian, skripsi, thesis, dan website yang membahas mengenai masalah yang akan diteliti. Selanjutnya penulis juga melakukan observasi untuk memperoleh pengumpulan data terkait permasalahan ini. Observasi yang dilakukan oleh penulis yaitu observasi langsung dan tidak langsung. Dalam tahap observasi langsung penulis mengamati kondisi new normal secara langsung, kemudian observasi tidak langsung penulis mengamati website dari Kemenkes RI yang membahas mengenai kebijakan new normal.

\section{Tahap Pengembangan}

Tahap kedua dalam penelitian ini yaitu tahap pengembangan yang menggunakan metode google design sprint. Tahap pengembangan dengan metode google design sprint dibagi menjadi lima tahap, yaitu:

\section{a) Tahap Understand}

Tahap pertama dalam proses pengembangan yaitu tahap understand. Penulis melakukan analisa mengenai masalah. Hal ini, dilakukan untuk memahami masalah secara mendalam, jika penulis sudah memahami masalah maka penulis bisa mengetahui langkah selanjutnya dalam merancang sebuah solusi. Penulis juga bisa mencari tahu informasi yang dibutuhkan, proses yang dilakukan juga tersusun secara sistematis. Setelah memahami masalah yang terjadi, selanjutnya penulis harus mencari informasi mengenai karakteristik tentang pengguna. Dengan mengetahui karakteristik pengguna, maka penulis akan memberikan solusi sesuai dengan kepribadian pengguna. Solusi tersebut akan dipertimbangkan oleh pengguna.

b) Tahap Diverge

Tahap selanjutnya adalah tahap diverge, untuk mendefinisikan dan mencari solusi dari permasalahan yang sudah ditemukan pada tahap sebelumnya. Tahap diverge dibagi menjadi dua tahapan lagi yaitu tahap challenge maps dan four steps sketch (Rustiaria, 2021). Challenge maps merupakan tahap dalam menyusun "how might we" untuk memunculkan banyak asumsi dalam menangani masalah tersebut. Setelah memunculkan masalah, langkah selanjutnya melakukan tahap four step sketch yang terdiri dari notes (mereview hasil analisis dengan cara menulis di note), ideas (penulis akan mengeksplor ide dengan cara membuat mind map), crazy $8 s$ (ide yang sudah dibuat dirancang kedalam 8 frame), solution sketch (memilih ide terbaik) (Abdillah, 2019). Solution sketch merupakan awal dari proses perancangan prototype.

\section{c) Tahap Decide}

Tahap ketiga adalah tahap decide yaitu menentukan ide terbaik dengan memusatkan semua ide menjadi satu ide utama. Dalam menentukan ide utama penulis menggunakan metode "The Sticky Decision" yang terdiri dari art museum, heat map, speed critique, straw poll, supervote (Maruf, 2021). Setelah mendapatkan ide terbaik, selanjutnya penulis membuat storyboard. Pembuatan storyboard berguna untuk mengetahui gambaran umum mengenai prototype. 
d) Tahap Prototype

Tahap berikutnya adalah tahap prototype. Proses pembuatan prototype berdasarkan storyboard yang sudah dirancang. Dalam pembuatan prototype dilakukan dengan melakukan empat aspek yaitu menentukan tools dalam menyusun prototype, menentukan komponen, menggabungkan komponen menjadi satu alur, memastikan prototype sesuai dengan rancangan yang diinginkan (Abdillah, 2019). Pada tahap ini penulis menggunakan Google Web Designer dalam merancang iklan responsif untuk mendesain iklan mengenai kebijakan new normal agar iklan yang dibuat oleh penulis menarik perhatian pelanggan.

e) Tahap Validate

Tahap terakhir dalam tahap pengembangan adalah tahap validate, dimana penulis melakukan validasi kepada pengguna mengenai hasil prototype. Tujuan dari tahap validate yaitu memastikan bahwa prototype yang dibuat sudah sesuai dengan tujuan awal. Tahap ini terdiri dari dua teknik yaitu small data dan interview (Abdillah, 2019). Teknik small data adalah teknik memperkenalkan prototype kepada pengguna, supaya mereka bisa berinteraksi dengan prototype. Kemudian teknik interview adalah teknik wawancara dengan pengguna dengan mengajukan pertanyaan yang berkaitan dengan prototype.

\section{Tahap Akhir}

Tahap akhir dalam penelitian ini yaitu penulis melakukan analisis dari tahap pengembangan, setelah menganalisa penulis akan menarik kesimpulan. Pada tahap ini penulis juga bisa menyimpulkan mengenai solusi yang dibuat sudah bisa menyelesaikan sebuah masalah. Selanjutnya hasil tersebut akan dibuat kesimpulan dan saran lalu dimasukan dalam laporan penelitian.

\section{HASIL DAN PEMBAHASAN}

Pada bab ini terdapat hasil serta pembahasan dari implementasi perancangan iklan web mengenai iklan layanan masyarakat "kebijakan new normal" yang terdapat pada web Kemenkes RI dengan menggunakan Google Web Designer. Desain iklan web yang digunakan pada ILM ini adalah desain responsif. Proses perancangan tersebut menggunakan metode design sprint, dimana terdapat beberapa tahap yang harus dilalui, berikut hasil dari tahapan yang sudah dilakukan.

\section{Hasil Tahap Awal}

Berdasarkan hasil identifikasi masalah serta studi literatur yang sudah dilakukan, ditemukan masalah yaitu terkait mengenai pengetahuan masyarakat terkait kebijakan baru yang dibuat oleh pemerintah yaitu kebijakan new normal, hal ini dilakukan untuk mengurangi angka penduduk yang terkena virus covid-19. Penyelesaian tersebut dilakukan dengan metode design sprint yang mencakup proses analisa serta perancangan iklan web. Selain studi literatur, tahapan ini terdapat juga proses observasi dimana penulis mengamati lingkungan sekitar serta mengamati website Kemenkes RI untuk mengindentifikasi masalah agar mengetahui proses yang akan diambil untuk tahap selanjutnya. Oleh karena itu tahap awal sangat penting dalam melanjutkan ke tahap selanjutnya. 


\section{Hasil Tahap Pengembangan}

Tahap pengembangan dilakukan dengan metode desain sprint, dimana terdapat beberapa tahapan yang harus dilaksanakan. Berikut hasil dari setiap tahapan yang terdapat pada metode desain sprint:

\section{Hasil Understand}

Understand merupakan tahap awal yang dilakukan pada tahap pengembangan. Pada tahapan ini terdiri dari dua proses yaitu mengidentifikasi masalah selanjutnya setelah mengetahui masalah yang terjadi, maka kita bisa mencari karakteristik user melalui pertanyaan yang terdapat pada google form, kemudian jawaban tersebut menunjang pengguna dijadikan user persona. Tahapan ini penulis menggunakan 3 sampel yang merupakan mahasiswa, yang mana mahasiswa merupakan salah satu pengguna aktif dalam menggunakan internet. Berikut hasil user persona dari pengguna internet berdasarkan hasil google form yang telah dilakukan.

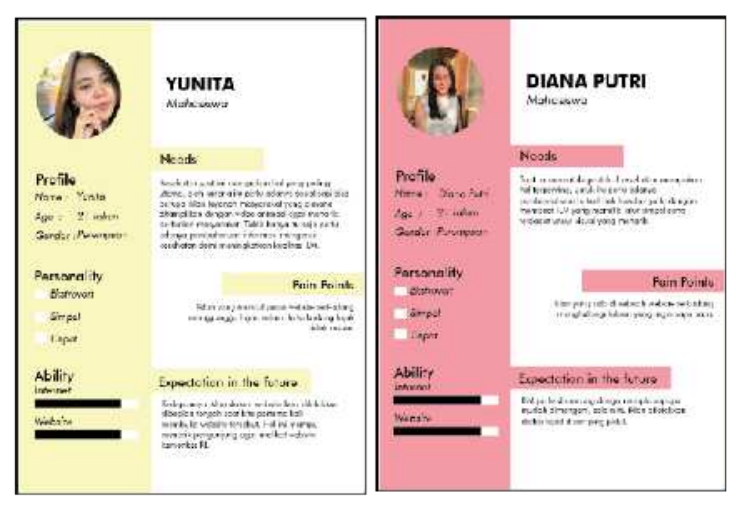

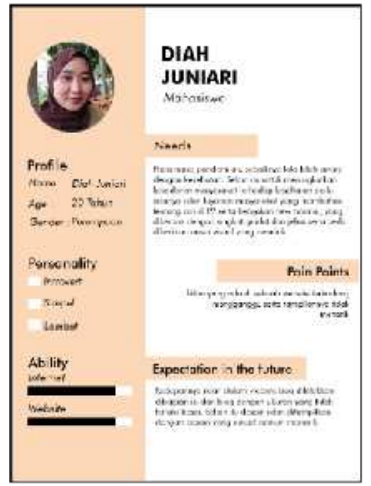

Gambar 2 Hasil user persona Sumber : Dokumentasi Penulis

Berdasarkan hasil user persona yang diwakilkan tiga orang mahasiswa ini, dapat disimpulkan bahwa dewasa ini terdapat masalah pada bidang kesehatan. Masa pandemi yang dialami saat ini menyebabkan kesehatan merupakan prioritas yang paling utama, di mana masyarakat harus meningkatkan kesadaran terhadap kesehatan serta kebersihan agar terhindar dari virus covid-19. Selain itu, saat ini pemerintah juga menetapkan kebijakan new normal, pemerintah sudah melakukan sosialisasi dengan menggunakan iklan layanan masyarakat yang ada di website Kemenkes RI namun tidak banyak masyarakat mengetahui hal ini. Oleh karena itu hasil dari ketiga user persona ini mengatakan bahwa iklan layanan masyarakat perlu diiklankan dengan cara yang simple dan jelas, selain itu tampilan iklan diberi unsur visual yang menarik seperti ilustrasi dan animasi. Namun hal ini terdapat kendala, salah satunya yaitu mengenai tata letak iklan pada website, menurut ketiga user persona ini iklan yang terdapat dalam website terkadang mengganggu pengguna saat ingin membaca isi website, oleh karena itu mereka menyarankan untuk menentukan tata letak iklan yang tepat di mana pengguna tidak terganggu dengan kehadiran sebuah iklan namun iklan tersebut 
masih terlihat oleh pengguna agar mereka bisa mebuka iklan web tersebut.

\section{Hasil Diverge}

Berdasarkan hasil dari mengidentifikasi masalah dan user persona yang dilakukan pada tahap sebelumnya maka selanjutnya dilakukan tahap menganalisis kebutuhan pada iklan web. Pada tahap diverge, dilakukan perancangan challenge map dengan menyusun "how might we" serta melakukan four step sketch, berikut hasil dari tahap diverge:

\section{a. Challenge map}

Challenge maps dirancang untuk mengetahui kebutuhan user yang akan dianalisa dengan membuat kemungkinan yang dapat dilakukan untuk menyelesaikan masalah yang terjadi. Hal ini dilakukan dengan menggunakan "how might we" (HMW). Berikut hasil dari challenge map :

Tabel 1 Tabel How Might We (HMW)

Sumber: Dokumentasi Penulis

\begin{tabular}{|c|c|c|c|}
\hline No & User's Needs & HMW & HMW Opportunites \\
\hline 1. & Informasi & $\begin{array}{l}\text { Bagaimana cara } \\
\text { memberitahukan } \\
\text { informasi kebijakan } \\
\text { new normal? }\end{array}$ & $\begin{array}{l}\text { Iklan Layanan } \quad \text { Masyarakat } \\
\text { berbasis website. }\end{array}$ \\
\hline \multirow[t]{3}{*}{2.} & \multirow[t]{3}{*}{ Display } & $\begin{array}{lr}\text { Bagaimana } & \text { cara } \\
\text { menarik } & \text { perhatian } \\
\text { pengguna } & \text { untuk } \\
\text { melihat Kemenkes RI? }\end{array}$ & $\begin{array}{l}\text { Iklan Web yang disebarkan di } \\
\text { berbagai situs web / blog. }\end{array}$ \\
\hline & & $\begin{array}{lr}\text { Bagaimana } & \text { tampilan } \\
\text { iklan yang } & \text { mudah } \\
\text { dipahami } & \text { oleh } \\
\text { pengguna? } & \end{array}$ & $\begin{array}{l}\text { Menggunakan copywriting yang } \\
\text { menarik, jelas, dan menarik }\end{array}$ \\
\hline & & $\begin{array}{l}\text { Bagaimana agar user } \\
\text { fokus dengan iklan } \\
\text { web yang ditampilkan? }\end{array}$ & $\begin{array}{l}\text { Menggunakan unsur visual yang } \\
\text { menarik bisa seperti ilustrasi, } \\
\text { animasi, foto yang berkualitas HD, } \\
\text { serta video dan lain-lain. }\end{array}$ \\
\hline 3. & Tata Letak & $\begin{array}{l}\text { Bagaimana agar user } \\
\text { tidak terganggu } \\
\text { dengan iklan yang ada } \\
\text { di sebuah website? }\end{array}$ & $\begin{array}{l}\text { Iklan web tersebut dibuat dengan } \\
\text { menggunakan desain responsif } \\
\text { yang dibuat dengan Google Web } \\
\text { Designer. }\end{array}$ \\
\hline
\end{tabular}




\section{b. Four Step Sketch}

Berdasarkan hasil dari challenge maps maka dilanjutkan dengan four step sketch yang akan menghasilkan solution sketch. Four step sketch terdiri dari empat tahapan yaitu :

- Notes

Notes merupakan tahap awal dalam four step sketch yaitu menganalisa hasil how might we kemudin menulis daftar idea yang akan digunakan dalam membuat iklan. Berikut note yang penulis buat dalam merancang iklan web.

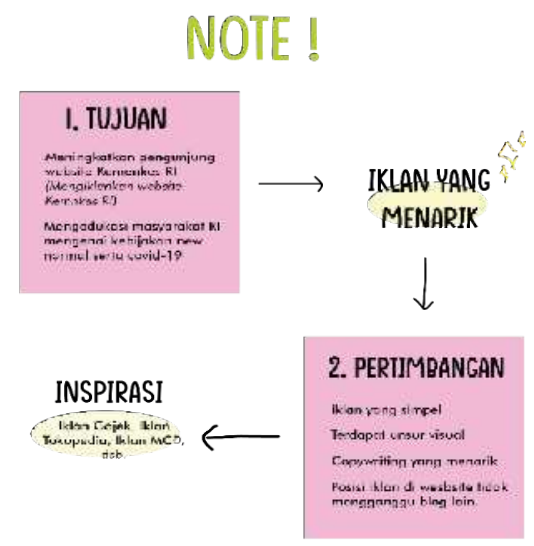

Gambar 3 Tahap Notes Sumber : Dokumentasi Penulis

\section{- Ideas}

Setelah membuat note maka tahap selanjutnya yaitu mengeksplorasi ide dengan menghubungkan ide satu dengan ide lainnya, berikut hasil dari tahap ideas.

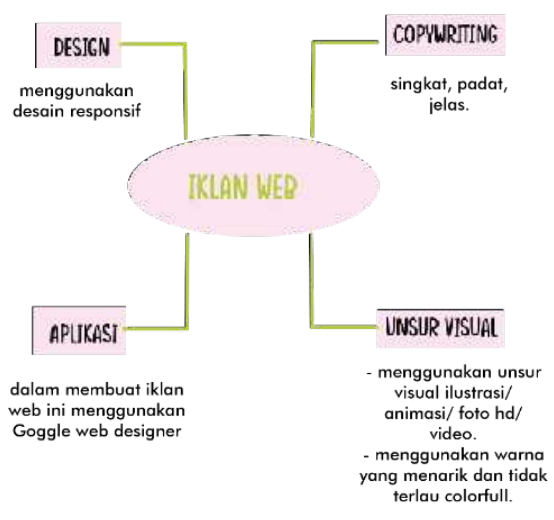

Gambar 4 Tahap Ideas Sumber : Dokumentasi Penulis

- Crazy 8s

Tahap ini akan dilakukan perancangan dengan membagi satu kertas menjadi delapan frame. Kemudian kedelapan frame tersebut diisi dengan ide-ide hasil dari analisis pada tahap sebelumnya. Ide pada tahap ini dibuat secara garis besar saja, berikut hasil crazy 8 s.

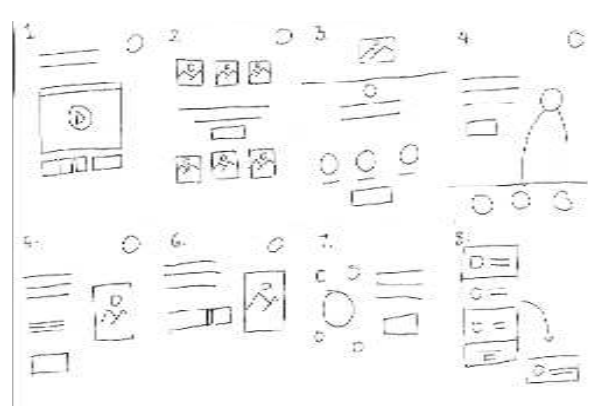

Gambar 5 Tahap Crazy $8 \mathrm{~s}$ Sumber: Dokumentasi Penulis

- Solution Sketch

Selanjutnya tahap ini merupakan tahap terakhir di solution sketch dimana memilih ide terbaik dari kedelapan ide yang sudah dibuat di tahap crazy 8s. Setelah memilih ide terbaik maka langkah selanjutnya 
yaitu membuat ide tersebut menjadi lebih detail. Hasil pada tahap ini akan digunakan untuk tahap selanjutnya yaitu membuat storyboard pada tahap decide. Berikut hasil dari solution sketch.

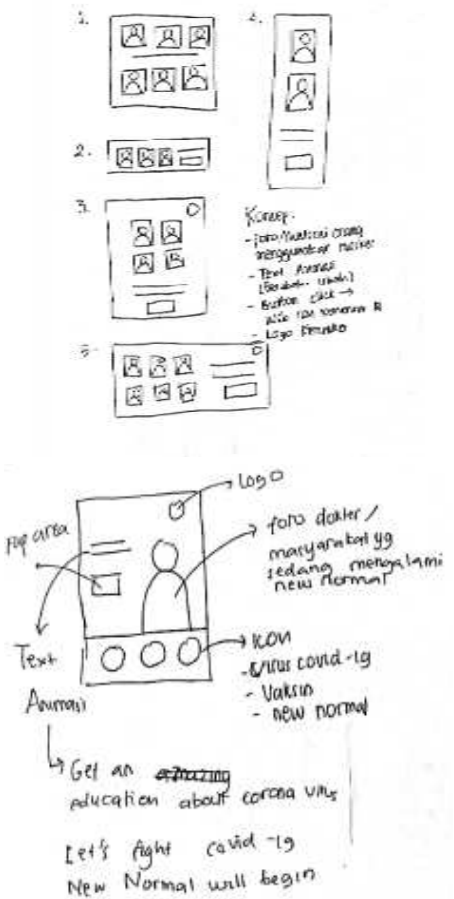

Gambar 6 Solution sketch Sumber : Dokumentasi Penulis

\section{Hasil Decide}

Pada tahap ini dilakukan langkah untuk menentukan ide terbaik yang selanjutnya akan diimplementasikan. Dalam menentukan ide tersebut, penelitian ini menggunakan teknik "The Sticky Note". Setelah mendapatkan ide yang terbaik maka ide tersebut divisualisasikan dengan merancang dari solution sketch menjadi storyboard. Tahap storyboard ini penulis merancang sketsa pada solution sketch secara lengkap kemudian akan menentukan hal-hal yang akan dimasukkan pada prototype ini. Berikut hasil dari storyboard untuk iklan web.

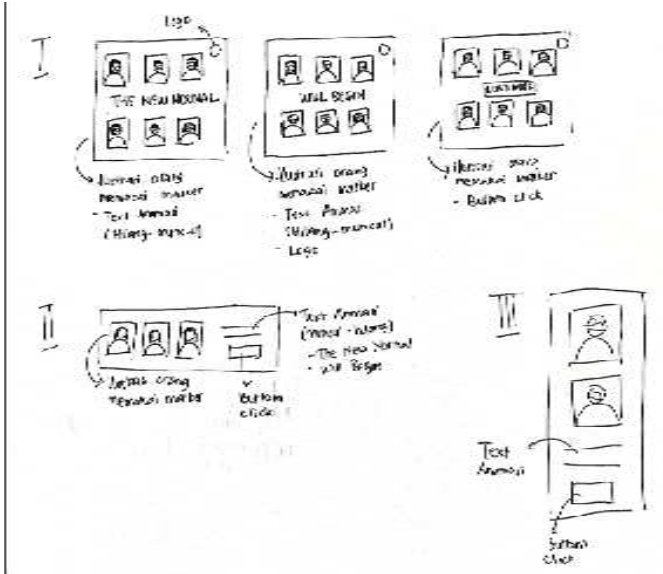

Gambar 7 Storyboard Ide 1 Sumber : Dokumentasi Penulis

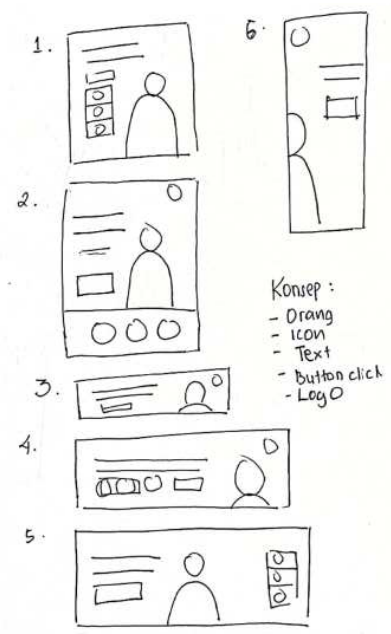

Gambar 8 Storyboard Ide 2 Sumber : Dokumentasi Penulis

Hasil Prototype

Setelah merancang sketsa prototype secara detail pada tahap storyboard, selanjutnya pada tahap ini dilakukan perancangan prototype. Proses prototyping ini menggunakan dua aplikasi yaitu adobe illustration serta google web designer. Aplikasi adobe illustration digunakan untuk merancang unsur visual yang terdapat pada iklan web, baik secara ilustrasi atau foto. Kemudian untuk aplikasi google web designer digunakan untuk menganimasikan text, mengatur layout pada iklan web dengan berbagai ukuran karena tema dari iklan web 
pada prototype ini menggunakan design responsif, serta menampilkan button click untuk mengakses website yang diklankan pada iklan web tersebut. Berikut adalah hasil prototype yang sudah dirancang.

- Hasil design prototype ide pertama

Pada design prototype yang pertama menggunakan konsep ilustrasi. Selain itu, desain ini menggunakan teks animasi isi teks animasi pada design pertama yaitu "The New Normal", "Will Begin" dan kemudian diukuran artboard 300x50, 250x250, 300x250 dilanjutkan dengan animasi click button yang akan mengakses website Kemenkes RI yang berisi Iklan Layanan Masyarakat tentang covid-19.

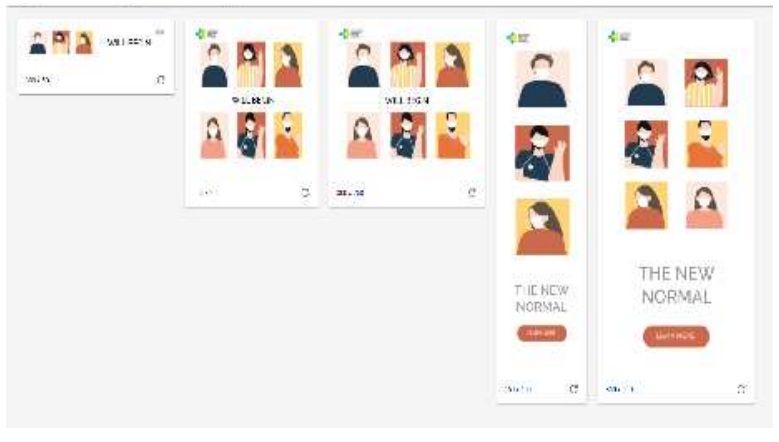

Gambar 9 Gambaran Awal Prototype Design 1 Sumber : Dokumentasi Penulis

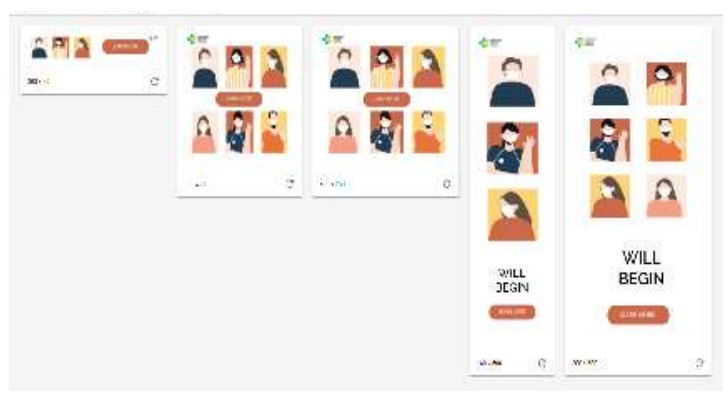

Gambar 10 Gambaran Akhir Prototype Design 1 Sumber : Dokumentasi Penulis

- Hasil design prototype kedua

Pada design prototype yang kedua elemen visualnya menggunakan foto. Selain itu, desain ini menggunakan teks animasi isi teks animasi pada design kedua yaitu "Get an education about covid-19", "Let's fight covid-19, new normal will begin" dan terdapat click button yang akan mengakses website Kemenkes RI yang berisi Iklan Layanan Masyarakat tentang covid-19.

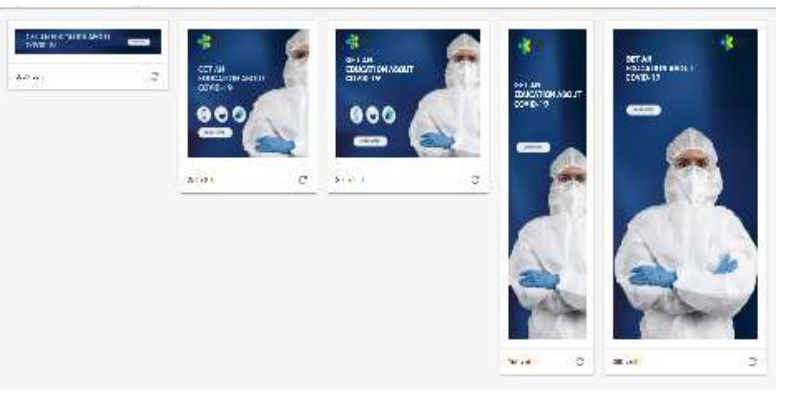

Gambar 11 Gambaran Awal Protype Design 2 Sumber : Dokumentasi Penulis

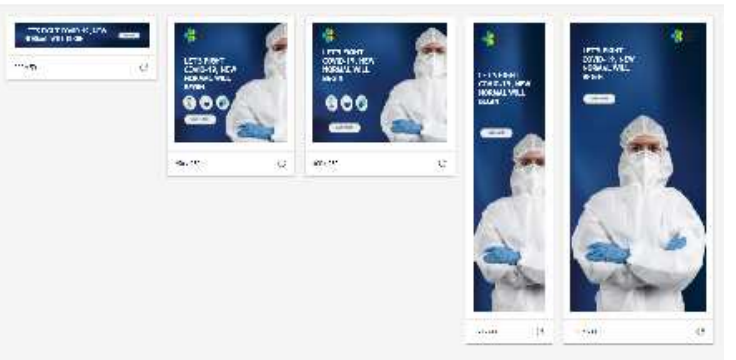

Gambar 12 Gambaran Akhir Prototype Design 2 Sumber : Dokumentasi Penulis

\section{Hasil Validate}

Setelah merancang prototype, maka dilanjutkan proses uji coba atau validate kepada ketiga user persona. Proses ini dilakukan dengan teknik user interview testing, dimana penulis akan menguji prototype dengan memberikan hasil prototype kepada user persona lalu ketiga user persona tersebut akan menjawab beberapa pertanyaan yang ada pada google form untuk mengetahui pendapat mereka mengenai prototype yang sudah dibuat. 


\section{Tahap Akhir}

Setelah melakukan semua tahapan pada tahap pengembangan, maka tahap ini merupakan tahap terakhir dimana dilakukannya dokumentasi serta dapat menarik kesimpulan berdasarkan hasil prototype tersebut.

\section{PEMBAHASAN}

Berdasarkan permasalahan yang terjadi saat ini, dimana kasus penyebaran penyakit virus covid-19 yang semakin tinggi ini, membuat website Kemenkes RI perlu disebarluaskan kepada khalayak, karena didalam website tersebut terdapat informasiinformasi mengenai virus covid-19 baik berupa cara pencegahan, vaksin, dan informasi lainnya yang masih berkaitan dengan covid-19. Untuk itu, penulis memberikan sebuah solusi untuk mengatasi permasalahan tersebut yaitu dengan membuat iklan web, hal ini dilakukan untuk membantu penyebaran website Kemenkes RI. Solusi ini dilakukan dengan melakukan metode Desain Sprint, yang terdiri dari beberapa tahapan yaitu understand, diverge, decide, validate. Dimana pada tahap understand menghasilkan pemahaman terhadap permasalahan yang terjadi oleh masyarakat saat ini. Tahap diverge merupakan tahapan yang dapat membantu masyarakat untuk menyelesaikan permasalahan dengan beberapa alternatif solusi. Kemudian tahap selanjutnya adalah tahap decide, dimana tahap ini penulis harus memilih alternatif solusi terbaik yang dapat memecahkan masalah ini. Setelah mendapatkan alternatif ide terbaik, maka selanjutnya alternatif ide tersebut dirancang sesuai dengan rancangan yang sudah dibikin. Setelah itu prototype diuji kepada user persona, tahap ini disebut tahap validate. Berdasarkan hasil uji validate, iklan web ini mendapatkan respon positif dari user persona baik dari unsur visual dan manfaatnya.

\section{KESIMPULAN}

Berdasarkan pembahasan tersebut, maka dapat disimpulkan bahwa:

1. Teknologi informasi merupakan sarana dalam menyampaikan dan menyebarkan sebuah informasi dengan cepat dan luas.

2. Iklan web dapat digunakan sebagai alternative dalam meningkatkan audiens untuk melihat ILM mengenai covid-19 pada web Kemenkes sehingga pesan yang terdapat dalam ILM tersampaikan.

3. Google Web Designer merupakan salah satu sarana dalam membuat iklan web secara mudah dan praktis, selain itu situs ini memiliki beberapa desain yang memudahkan bagi kaum pemula. Salah satu fitur yang menarik adalah desain responsif, dimana desain ini memiliki berbagai ukuran sehingga iklan yang kita buat mampu ditaruh di berbagai ukuran website. Hal ini membantu meningkatkan audiens.

\section{DAFTAR PUSTAKA}

[1] Abdillah, M. A. (2019) Evaluasi dan Perbaikan Rancangan User Interface Pada Website Surabaya Mengaji Menggunakan Design Sprint. Institut Bisnis dan Informatika STIKOM Surabaya.

[2] Agung, I. M. (2020) 'Memahami Pandemi Covid-19 Dalam Perspektif Psikologi Sosial', Psikobuletin:Buletin Ilmiah Psikologi, 1(2), pp. 68-84. Available at: http://ejournal.uinsuska.ac.id/index.php/Psikobuletin/article /view/9616/5058.

[3] Anung Ahadi Pradana, Casman, N. (2020) 'Pengaruh Kebijakan Social Distancing pada Wabah COVID-19 terhadap 
Kelompok Rentan di Indonesia', Jurnal Kebijakan Kesehatan Indonesia: JKKI, 9(2), pp. 61-67. Available at: https://jurnal.ugm.ac.id/jkki/article/view/ 55575.

[4] Arrosyid, R. A. (2020) Analisis Tanda Verbal Pada Iklan Online Produk Perawatan Kulit Senka Tahun 2018-2020. Universitas Airlangga. Available at: http://repository.unair.ac.id/id/eprint/101 896.

[5] Hakim, L. and Oktariandi, M. A. (2017) 'Perancangan Sistem Tracer Alumni STMIK Musi Rawas Berbasis Web Mobile', Jusim, 2(2), pp. 108-116.

[6] Ilpaj, S. M. and Nurwati, N. (2020) 'Analisis Pengaruh Tingkat Kematian Akibat Covid-19', Jurnal Pekerjaan Sosial, 3(1), pp. 16-28.

[7] Irso (no date) Dirjen PPI: Survei Penetrasi Pengguna Internet di Indonesia Bagian Penting dari Transformasi Digital. Available at: https://www.kominfo.go.id/content/detail /30653/dirjen-ppi-survei-penetrasipengguna-internet-di-indonesia-bagianpenting-dari-transformasidigital/0/berita_satker.

[8] Januar Mahardhani, A. (2020) 'Menjadi Warga Negara yang Baik pada Masa Pandemi Covid-19: Persprektif Kenormalan Baru', Jurnal Pancasila dan Kewarganegaraan, 5(2), pp. 65-76. doi: 10.24269/jpk.v5.n2.2020.pp65-76.

[9] Karwati, L. et al. (2021) 'Meningkatkan Kedisiplinan Dan Pembiasaan Masyarakat Dalam Menghadapi New Normal Untuk Mencegah Penyebaran Covid19', Jurnal Abdimas Siliwangi, 04(01), pp. 138-146.

[10] LALU, R. M. W. (2019) Sistem Informasi Pariwisata Kabupaten Manggarai Barat Menggunakan Responsif Web Desain, Journal of Chemical Information and Modeling. Sekolah Tinggi Manajemen Informatika Dan Komputer AKAKOM
Yogyakarta. Available at: http://eprints.akakom.ac.id/8293/.

[11] Martana, I. K. (2018) 'Efektivitas Iklan Televisi Teh Botol Sosro Tawar Versi Natural dan Fresh dengan Direct Rating Method (DRM)', Seminar Nasional Inovasi dan Tren 2018. Available at: https://repository.bsi.ac.id/index.php/und uh/item/289507/Prosiding-SNIT-I-KetutMartana.pdf.

[12] Maruf, B. R. (2021) Perancangan Design UI/ UX Pada Aplikasi UKMKU Berbasis Mobile Menggunakan Metode Design Sprint. Universitas Dinamika.

[13] Muslihudin, M. and Setiawan, Y. (2019) 'Sistem Informasi Dinas Perikanan Kabupaten Tanggamus Berbasis Web Mobile', 02(01), pp. 21-26.

[14] Prabowo, Y. A. (2020) LKP : Rancang Bangun Sistem Informasi Pendaftaran Rawat Jalan Berbasis Website pada Rumah Sakit Ibu dan Anak Putri Surabaya. Institut Bisnis dan Informatika Stikom Surabaya. Available

$$
\text { at: }
$$
http://repository.dinamika.ac.id/id/eprint 13725 .

[15] Pramonoadi, D. W. (2017) Mplementasi Responsive Web Dengan Menggunakan Framework Bootstrap Di Rumah Makan Studi Kasus Ramen 'N Katsu. Sekolah Tinggi Manajemen Informatika dan Komputer AKAKOM Yogyakarta. Available at: www.journal.uta45jakarta.ac.id.

[16] Pratiwi, S. A. and Hidayat, D. (2020) 'Iklan Layanan Masyarakat COVID-19 Di Media Sosial dan Perilaku Masyarakat di Jawa Barat', Komunikologi (Jurnal Ilmiah Ilmu Komunikasi), 17(2), pp. 1-7.

[17] Ramadan, R., Muslimah, A.-Z. H. and Rokhmawati, R. I. (2019) 'Perancangan User Interface Aplikasi EzyPay menggunakan Metode Design Sprint (Studi Kasus PT. Arta Elektronik Indonesia), Jurnal Pengembangan Teknologi Informasi dan Ilmu Komputer 
(J-PTIIK) Universitas Brawijaya, 3(9), pp. 8831-8840. Available at: https://jptiik.ub.ac.id/index.php/jptiik/article/view/6272/3019.

[18] Rori, Y. (2018) Aplikasi Mobile Web Penjualan Produk Goddesskin Pada Athena Skin Care Menggunakan Metode Fast. Politeknik Negeri Sriwijaya.

[19] Rudianto et al. (2018) 'Perancangan Animasi Multimedia Iklan Layanan Masyarakat Tentang Proses Pembuatan EKTP', Jurnal Akrab Juara, 3(1), pp. 31-38.

[20] Rustiaria, A. W. (2021) Analisis dan Perancangan User Interface/ User Experience Pada Website Kemahasiswaan Universitas Dinamika Menggunakan Metode Google Design Sprint. Universitas Dinamika. Available at: http://repository.dinamika.ac.id/id/eprint /5559/9/17410100121-2021UNIVERSITASDINAMIKA.pdf.

[21] Sitepu, A. I. B. and Tanjung, D. Y. H. (2020) 'Rancang Bangun Aplikasi Pemesanan dan Penjualan Berbasis Web dan Android Pada Toko YT.Wall Interior', Jurnal FTIK, 1. Available at: http://ejournal.potensi-

utama.ac.id/ojs/index.php/FTIK/article/vi ew/927.

[22] Usmanto, B. et al. (2018) 'Implementasi Web Mobile Sebagai Mediainformasi Pemberdayaan Masyarakat Di Desa Pirngadi', Jurnal Keteknikan dan Sains, 1(1), pp. 32-40. Available at: http://journal.unhas.ac.id/index.php/jutek s/article/view/4296. 